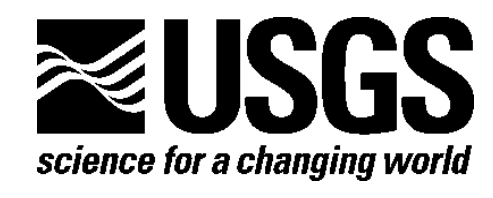

\title{
Coastal Change on Gulf Islands National Seashore during Hurricane Gustav: West Ship, East Ship, Horn, and Petit Bois Islands
}

Hilary F. Stockdon, Kara S. Doran, and Katherine A. Serafin

Open-File Report 2010-1090

U.S. Department of the Interior

U.S. Geological Survey 


\section{U.S. Department of the Interior \\ KEN SALAZAR, Secretary}

\section{U.S. Geological Survey \\ Marcia K. McNutt, Director}

U.S. Geological Survey, Reston, Virginia 2009

For product and ordering information:

World Wide Web: http://www.usgs.gov/pubprod

Telephone: 1-888-ASK-USGS

For more information on the USGS-the Federal source for science about the Earth, its natural and living resources, natural hazards, and the environment:

World Wide Web: http://www.usgs.gov

Telephone: 1-888-ASK-USGS

Suggested citation:

Stockdon, H.F., Doran, K.S., and Serafin, K.A., 2010, Coastal change on Gulf Island National Seashore during Hurricane Gustav: West Ship, East Ship, Horn, and Petit Bois Islands: U.S. Geological Survey Open-File Report 2010-1090, 18 p., online only.

Any use of trade, product, or firm names is for descriptive purposes only and does not imply endorsement by the U.S. Government.

Although this report is in the public domain, permission must be secured from the individual copyright owners to reproduce any copyrighted material contained within this report. 


\section{Contents}

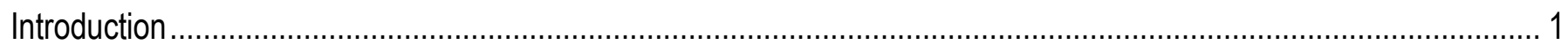

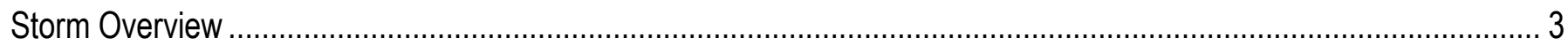

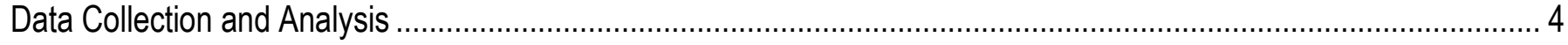

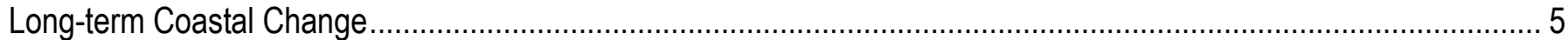

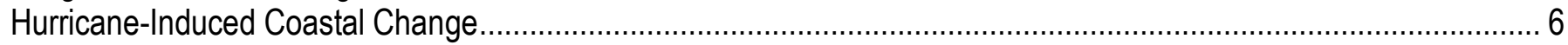

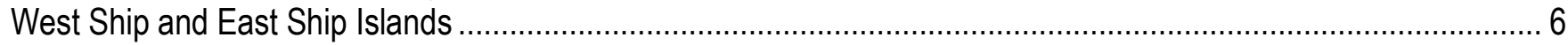

Horn Island.

Petit Bois Island ……………………

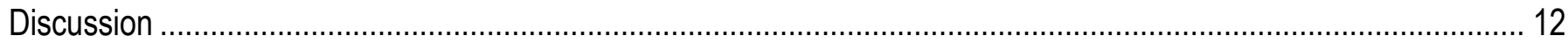

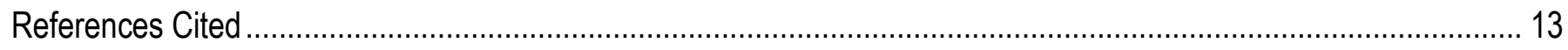

\section{Figures}

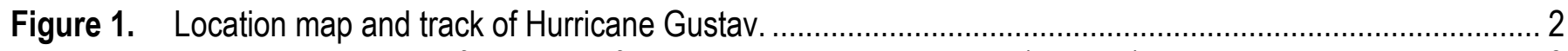

Figure 2. Pre-storm elevation of the crest of the most seaward sand dune (or berm) ....................................... 3

Figure 3. Dune elevation (top), shoreline (middle), and beach volume (bottom) changes for West Ship and East Ship Islands, calculated between June 27-29, 2007 and September 8, 2008.

Figure 4. Shoreline changes for Ship (top), Horn (middle), and Petit Bois (bottom) Islands resulting from the landfalls of Hurricanes Katrina and Gustav.

Figure 5. Dune elevation (top), shoreline (middle), and beach volume (bottom) changes for Horn Island, calculated between June 27-29, 2007 and September 8, 2008.

Figure 6. Dune elevation (top), shoreline (middle), and beach volume (bottom) changes for Petit Bois Island, calculated between June 27-29, 2007 and September 8, 2008. 


\section{Conversion Factors}

\section{SI to Inch/Pound}

\begin{tabular}{lcl}
\hline \multicolumn{1}{c}{ Multiply } & By & \multicolumn{1}{c}{ To obtain } \\
\hline centimeter $(\mathrm{cm})$ & 0.3937 & inch (in) \\
millimeter $(\mathrm{mm})$ & 0.03937 & inch (in) \\
meter $(\mathrm{m})$ & 3.281 & foot (ft) \\
kilometer $(\mathrm{km})$ & 0.6214 & mile (mi) \\
kilometer $(\mathrm{km})$ & 0.5400 & mile, nautical $(\mathrm{nmi})$ \\
meter $(\mathrm{m})$ & 1.094 & yard $(\mathrm{yd})$ \\
\hline & Area & \\
\hline square meter $\left(\mathrm{m}^{2}\right)$ & 0.0002471 & acre \\
square kilometer $\left(\mathrm{km}^{2}\right)$ & 247.1 & acre \\
square meter $\left(\mathrm{m}^{2}\right)$ & 10.76 & square foot $\left(\mathrm{ft}^{2}\right)$ \\
square kilometer $\left(\mathrm{km}^{2}\right)$ & 0.3861 & square mile $\left(\mathrm{mi}^{2}\right)$ \\
\hline & Volume & \\
\hline cubic meter $\left(\mathrm{m}^{3}\right)$ & 35.31 & cubic foot $\left(\mathrm{ft}^{3}\right)$ \\
cubic meter $\left(\mathrm{m}^{3}\right)$ & 1.308 & cubic yard $\left(\mathrm{yd}^{3}\right)$ \\
\hline & Flow rate & \\
\hline kilometer per hour $(\mathrm{km} / \mathrm{h})$ & 0.6214 & mile per hour $(\mathrm{mi} / \mathrm{h})$ \\
\hline
\end{tabular}

Vertical coordinate information is referenced to North American Vertical Datum of 1988 (NAVD 88) Horizontal coordinate information is referenced to the North American Datum of 1983 (NAD 83) 


\section{Coastal Change on Gulf Islands National Seashore during Hurricane Gustav: West Ship, East Ship, Horn, and Petit Bois Islands}

Hilary F. Stockdon, Kara S. Doran, and Katherine A. Serafin

\section{Introduction}

Hurricane Gustav made landfall on September 1, 2008, near Cocodrie, Louisiana, as a category 2 storm, with maximum sustained winds near $170 \mathrm{~km} / \mathrm{hr}$ (fig. 1). Hurricane-force winds, with speeds in excess of $119 \mathrm{~km} / \mathrm{hr}$, extended along $270 \mathrm{~km}$ of the Louisiana coastline, from Marsh Island to the central barrier islands. Tropical-storm-force winds (speeds $>63 \mathrm{~km} / \mathrm{hr}$ ) were felt across the coasts of Mississippi and Alabama. Within this area of high wind and associated storm surge and waves lie the Mississippi barrier islands of West Ship, East Ship, Horn, and Petit Bois, part of the National Park Service (NPS) Gulf Islands National Seashore (GUIS).

These east-west trending islands form a barrier between the Mississippi Sound to the north and the Gulf of Mexico to the south. The islands are generally less than $1 \mathrm{~km}$ wide with dune elevations ranging generally between 2 and $3 \mathrm{~m}$, but reaching $6 \mathrm{~m}$ on Horn Island (fig. 2). The interaction of waves and currents with the low, sandy beaches forces a range of dynamic responses, such as dune erosion, overwash deposition, spit elongation, and island breaching. The passage of strong hurricanes (such as Camille in 1969 and Katrina in 2005), combined with a background signal of long-term shoreline retreat, has caused significant coastal changes on the Mississippi barrier islands, presenting management challenges for State and Federal officials, including NPS resource managers.

At the request of the NPS, the U.S. Geological Survey (USGS) has processed, analyzed, and interpreted pre- and post-Hurricane-Gustav lidar topographic data for West Ship, East Ship, Horn, and Petit Bois. These data and analyses can be used to better assess the storm vulnerability of portions of GUIS by characterizing the magnitude and spatial variability of hurricane-induced coastal changes, such 
as shoreline retreat, dune erosion, and beach volume change. This information will provide park managers with a greater understanding of the long-term evolution of these islands, which are frequently impacted by coastal storms. The purpose of this report is to summarize the methods used and observations made during a study of the effects of Hurricane Gustav on the coastal morphology of four island in GUIS.

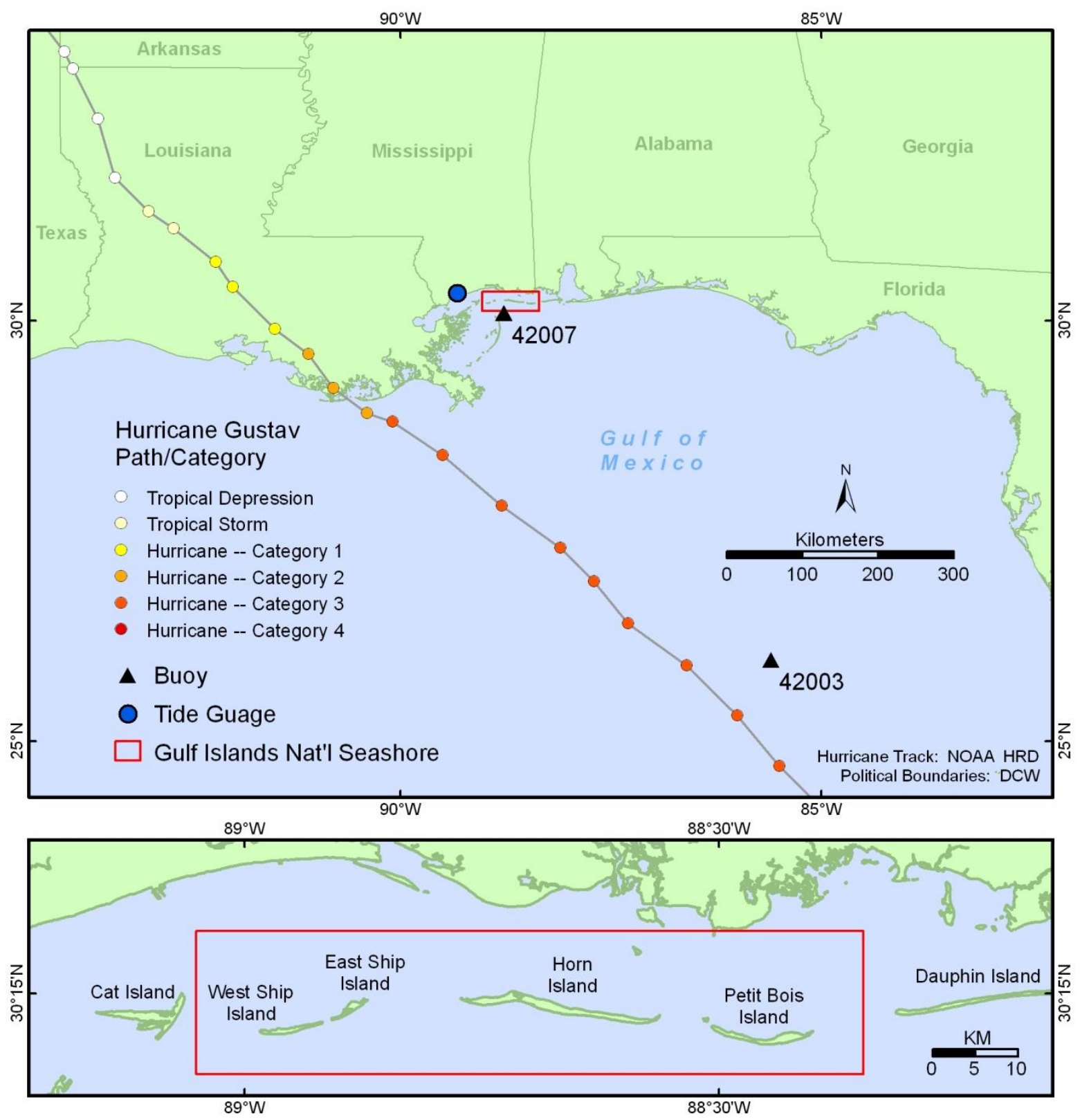

Figure 1. Location map and track of Hurricane Gustav. Hurricane track information (top) was obtained from Bevin and Kimberlain (2009). The location of NDBC buoys and NOAA tide gages are also shown (top). The red boxes indicate the area of focus (top and bottom). 


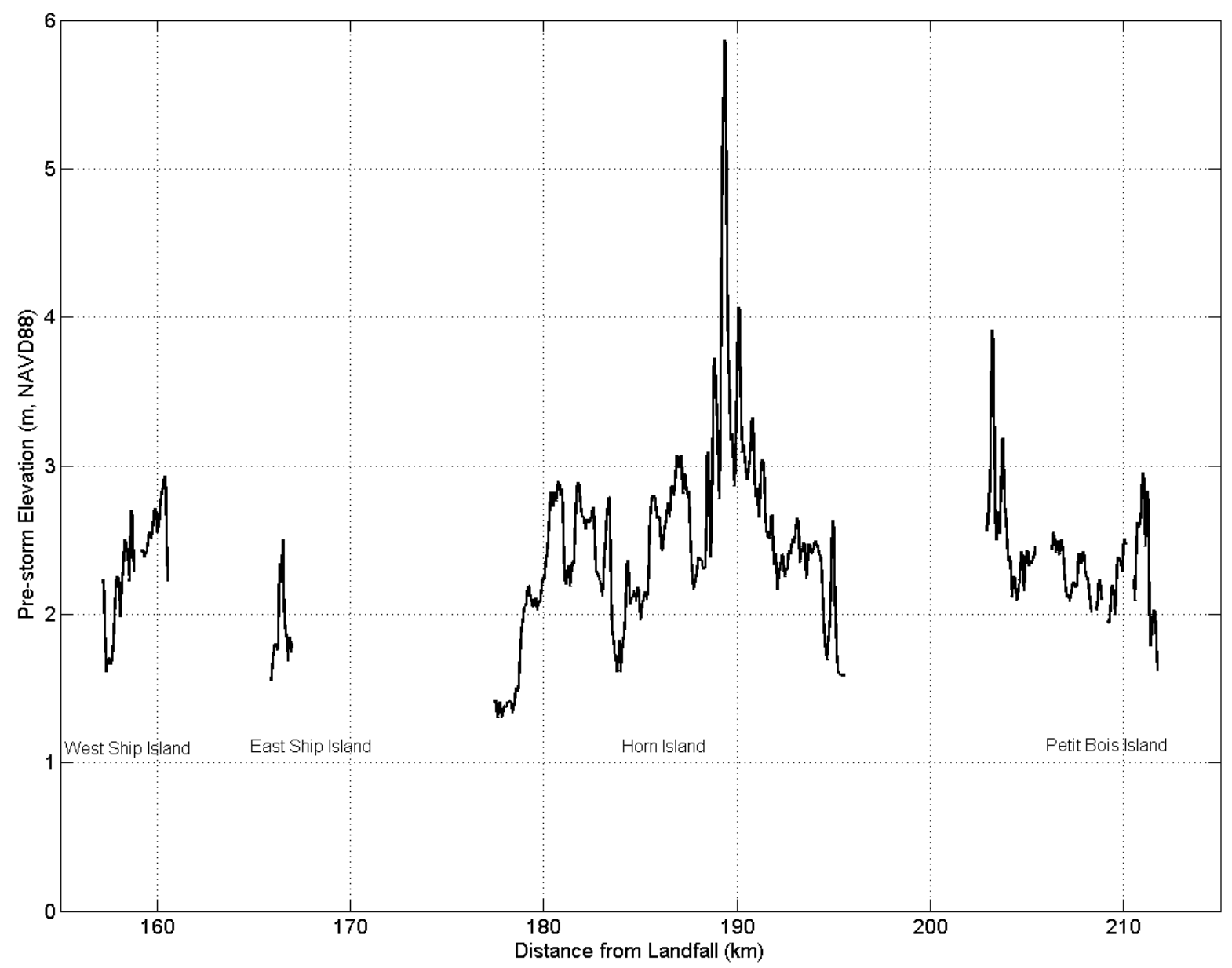

Figure 2. Pre-storm elevation of the crest of the most seaward sand dune (or berm) measured on June 27-29, 2007.

\section{Storm Overview}

As Hurricane Gustav moved northwest across the Gulf of Mexico, category 3 strength winds (speed $>178 \mathrm{~km} / \mathrm{hr}$ ) forced large storm waves towards the Louisiana and Mississippi coasts. The maximum significant wave height recorded at a National Oceanic and Atmospheric Administration (NOAA) National Data Buoy Center (NDBC) deep-water buoy (42003, fig. 1), located approximately $458 \mathrm{~km}$ south of Panama City, Fla, was $10.34 \mathrm{~m}$ with a wave period of $13.8 \mathrm{~s}$ (National Data Buoy Center, 2008). The maximum wave height offshore of the Mississippi barrier islands was observed to be $6.6 \mathrm{~m}$ at a NDBC buoy (42007, fig. 1), located 44 km south-southeast of Biloxi, Miss., in 14-m water depth (National Data Buoy Center, 2008). At this location, lower wave heights were observed because of dissipation over the broad continental shelf and waves breaking further offshore. 
The highest water levels during Hurricane Gustav were observed approximately $100 \mathrm{~km}$ east of landfall. NOAA coastal tide gages recorded a maximum storm surge of $1.37 \mathrm{~m}$ at landfall near Grand Isle, La. However, $130 \mathrm{~km}$ east of landfall in Bay St. Louis, Miss., the maximum observed storm surge was $3.01 \mathrm{~m}$ (NOAA station 8747437; fig. 1). Water levels remained elevated by $1 \mathrm{~m} 24 \mathrm{hrs}$ after landfall. Recorded surge height peaked at $1.04 \mathrm{~m}$ in Gulfport, Miss., before the gage failed. Surveyed high water marks at Fort Massachusetts, on Ship Island, indicate that surge levels were $1.98 \mathrm{~m}$ above the high tide line (Hopkins, 2009).

\section{Data Collection and Analysis}

On September 5 to 8, 2008, high-resolution lidar surveys of the coastline impacted by Hurricane Gustav were performed. Post-storm topographies of the sandy barrier islands of Louisiana, Mississippi, Alabama, and the panhandle of Florida were mapped using the USGS Experimental Advanced Airborne Research Lidar (EAARL) system. The survey covered $570 \mathrm{~km}$ of coastline in four days, collecting a measurement of island elevation approximately every square meter.

The portion of GUIS that includes West Ship, East Ship, Horn, and Petit Bois Islands was surveyed on September 8, 2008. Details of the USGS data collection effort for Hurricane Gustav can be found in Doran and others (2009).

First- and last-return lidar data were processed according to methods outlined in Bonisteel and others (2009). Final elevations are relative to the North American Vertical Datum (NAVD). First-return data measure the elevation of the first surface encountered by the laser, including returns off trees and other vegetation. Last-return lidar data measure the elevation of a bare-Earth surface, including elevations under vegetation. To quantify hurricane-induced coastal change, the lidar data were compared to elevations measured prior to storm landfall. For this study, the pre-storm data were collected by the EAARL system on June 27 to 29, 2007, just over a year before Hurricane Gustav landfall.

Last-return lidar data, both pre- and post-storm, were interpolated to a gridded domain, with 2.5$\mathrm{m}$ resolution in the cross-shore and 10-m resolution in the longshore. The interpolation method allows for definition of a root-mean-square (rms) error at each point, evaluation of data quality, and identification/removal of noise (Plant and others, 2002). The elevation and error grids were used to 
measure pre- and post-storm beach morphology, including features such as shoreline position, dune elevation, and beach volume.

The cross-shore position of a vertical-datum-based shoreline was extracted from shore-paralleloriented grids of beach topography (Stockdon and others, 2002). The vertical shoreline datum was defined as the mean-high-water level from tidal records (Weber and others, 2005) and is approximately $0.23 \mathrm{~m}$ above NAVD88 along the Mississippi barrier islands of GUIS. The cross-shore location and peak elevation of the seaward-most sand dune were also extracted from gridded, pre-storm lidar topography (Stockdon and others, 2009). Beach volume was quantified from gridded data between the cross-shore locations of the pre-storm dune base and the pre-storm shoreline. Coastal change was calculated as the difference between pre- and post-storm shoreline position and beach volume, as well as the elevation difference at the geographic location of the pre-storm dune crest. Ephemeral spits located on the ends of the islands were not considered in this analysis. Because these dynamic features, typically less than $50 \mathrm{~m}$ wide with peak elevations between 1 and $1.5 \mathrm{~m}$, respond so rapidly to waves and tidal flows, the 2007 pre-storm lidar data for the ephemeral spits were likely an inaccurate representation of their topography at the time of Hurricane Gustav landfall.

\section{Long-term Coastal Change}

When examining the role of hurricane landfalls on morphologic change on the Mississippi barrier islands, it is important to consider the rates of historic coastal change Over the past 150 years, the Mississippi barrier islands have been migrating laterally to the west in response to a dominant westerly longshore transport driven by southerly and southeasterly winds (Boone, 1973; Byrnes and others, 1991; Morton, 2008). The long-term migration rates for the western ends of the islands range from 10 to $50 \mathrm{~m} / \mathrm{yr}$, with the fastest rates observed on Petit Bois and Horn Islands (Byrnes and others, 1991). Shorelines on the western ends of the islands have been accreting Gulfward at a rate of approximately $1 \mathrm{~m} / \mathrm{yr}$, while eastern shorelines have been retreating at rates of 2 to $6 \mathrm{~m} / \mathrm{yr}$ (Byrnes and others, 1991; Miller and others, 2004). Westward migration of West Ship Island has been limited by the presence of maintained navigation channels. In addition to the lateral shifting of the islands, they have also narrowed on both the Gulf and Mississippi sides in response to shoreline erosion due to longshore and cross-shore sediment transport (Morton, 2008). 


\section{Hurricane-Induced Coastal Change}

All four islands experienced extensive changes in shoreline position, dune elevation, and beach volume during Hurricane Gustav. Spatial variability in the coastal response was observed along a single island as well as between islands (figs. $3-6$ ).

\section{West Ship and East Ship Islands}

Shoreline change along West Ship Island was highly variable, ranging from over $50 \mathrm{~m}$ of erosion to $50 \mathrm{~m}$ of accretion (table 1 ; fig. 3 ). The range of values of shoreline change were similar to that observed following the landfall of Hurricane Katrina in September 2005 (fig. 4). Volume change was also highly variable with areas of erosion located next to areas of accretion. This pattern of sand loss and gain, in both shoreline position and beach volume changes, occurred in multiple locations where there was an abrupt change in shoreline orientation, and is typically associated with sediment transport along, rather than offshore of, the coast. The change in shoreline orientation at this location created variations in wave angle and height, forcing gradients in the alongshore flow and sediment transport.

The magnitudes of shoreline change were much greater on East Ship Island, where mean shoreline retreat was $122 \mathrm{~m}$ (table, 1; fig. 3). This is almost two times greater than the amount of erosion experienced during Hurricane Katrina, when the mean shoreline retreat was $67 \mathrm{~m}$ (fig. 4). The extent of shoreline retreat, combined with large losses of beach volume, indicates that waves and currents during Hurricane Gustav have countered island recovery since Katrina, and actually furthered land loss.

On the east and west parts of Ship Island, there was an overall loss of island elevation following hurricane landfall (table 1, fig. 3). Mean elevation change at the dune /berm crest on West and East Ship Islands was $-0.75 \mathrm{~m}$ and $-1.02 \mathrm{~m}$, respectively. This loss in elevation has likely made the islands more vulnerable to continued erosion during future storms and, potentially, smaller wave events.

Table 1. Mean (standard deviation) coastal change between June 27-29, 2007 and September 8, 2008.

\begin{tabular}{lllll}
\hline & Shoreline Change $(\mathbf{m})$ & $\begin{array}{l}\text { Beach Volume Change } \\
\left(\mathbf{m}^{3} / \mathbf{m}\right)\end{array}$ & $\begin{array}{l}\text { Dune Elevation Change } \\
(\mathbf{m})\end{array}$ & $\begin{array}{l}\text { Pre-storm Dune } \\
\text { Elevation }(\mathrm{m})\end{array}$ \\
\hline West Ship Island & $-8.22(31.30)$ & $-25.94(27.03)$ & $-0.75(0.71)$ & $2.07(0.49)$ \\
East Ship Island & $-122.52(43.54)$ & $-34.12(30.95)$ & $-1.02(0.76)$ & $1.77(0.36)$ \\
Horn Island & $-13.17(24.54)$ & $-33.94(44.22)$ & $-0.02(0.22)$ & $2.53(0.58)$ \\
Petit Bois Island & $-14.78(13.58)$ & $-34.60(16.72)$ & $-0.08(0.18)$ & $2.38(0.37)$ \\
\hline
\end{tabular}




\section{West Ship Island}

\section{East Ship Island}
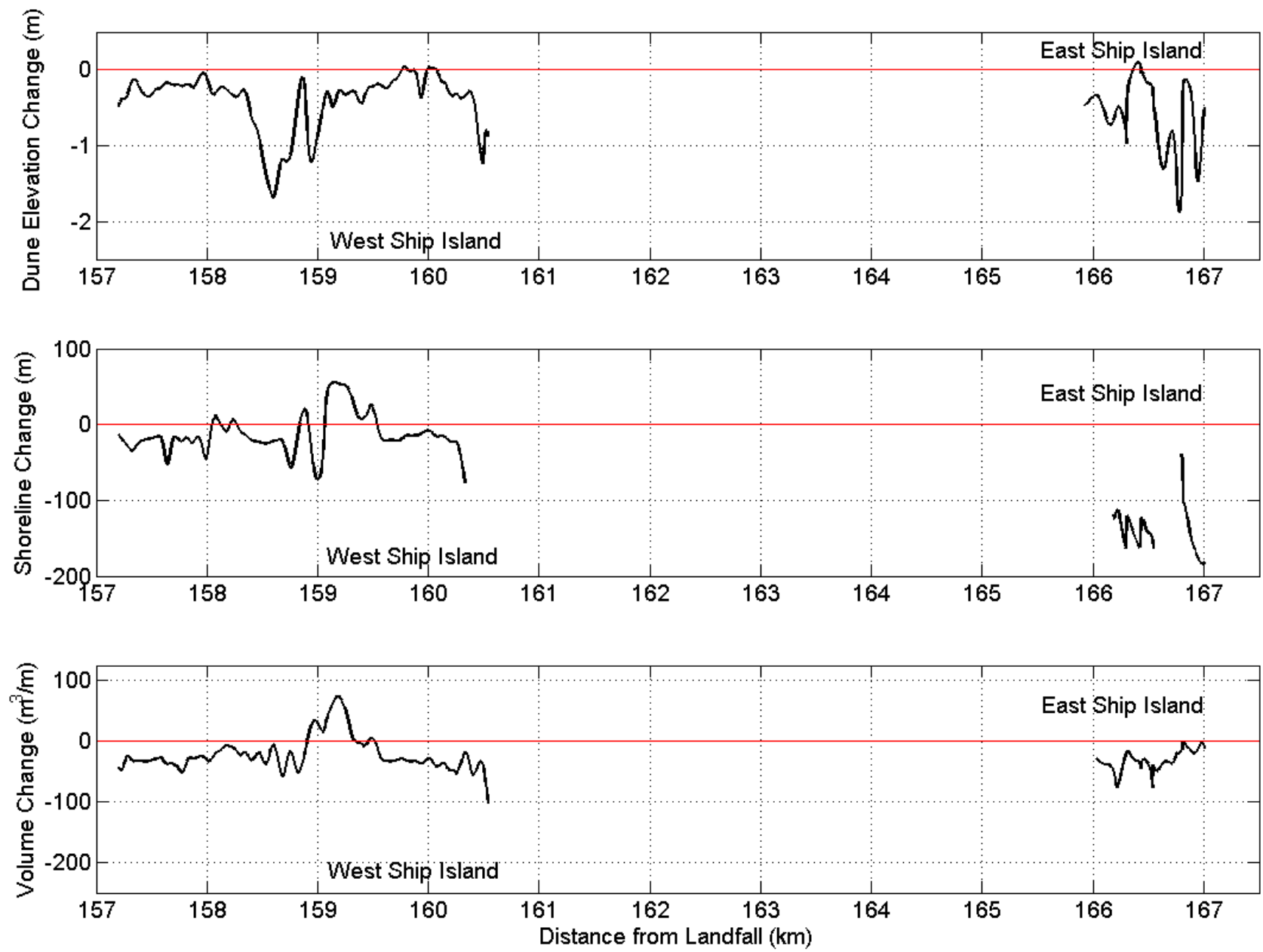

Figure 3. Aerial photograph taken by the U.S. Department of Agriculture on September 17, 2007. Dune elevation (top), shoreline (middle), and beach volume (bottom) changes for West Ship and East Ship Islands, calculated between June 27-29, 2007 and September 8, 2008 

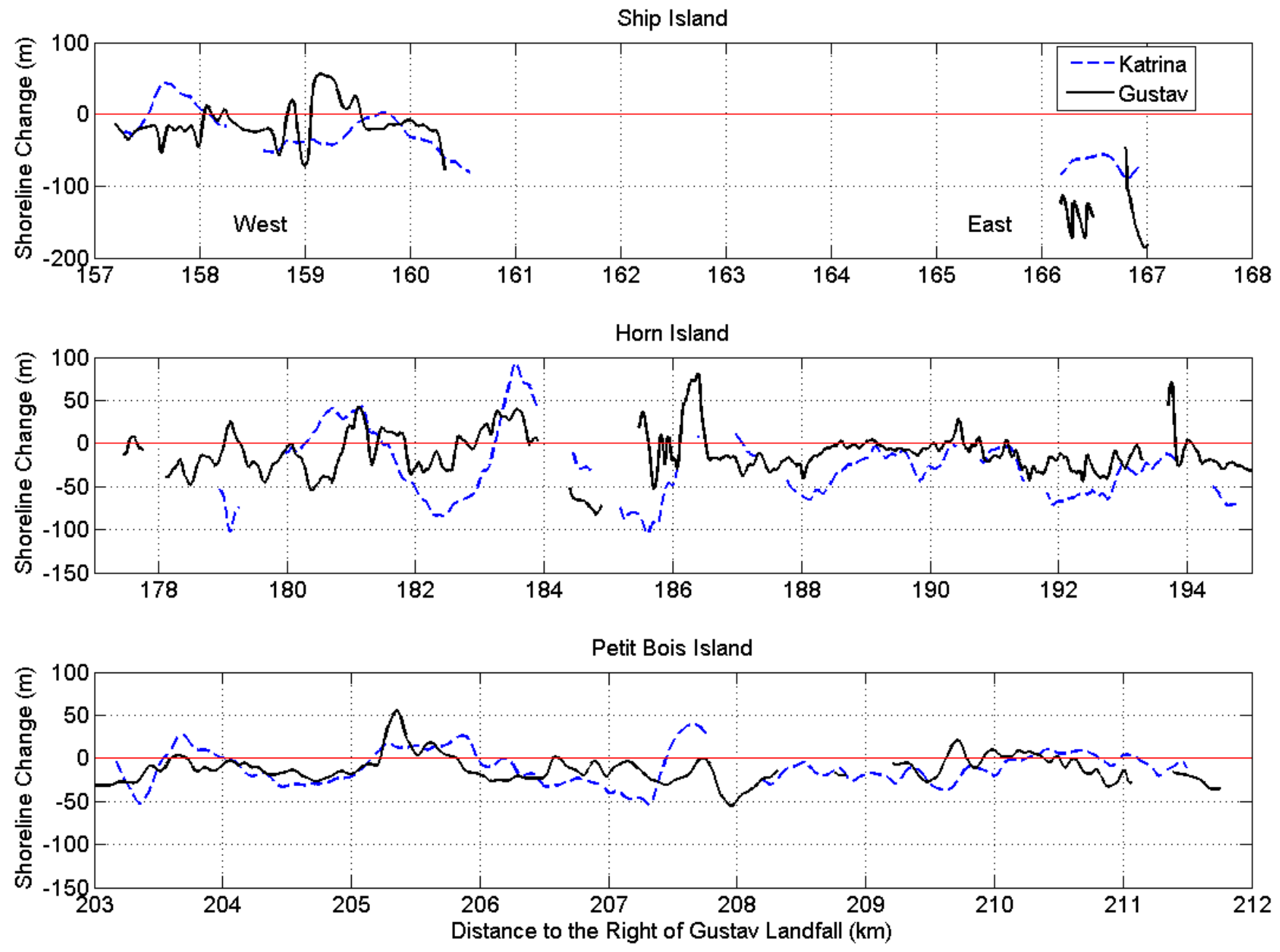

Figure 4. Shoreline changes for Ship (top), Horn (middle), and Petit Bois (bottom) Islands resulting from the landfalls of Hurricanes Katrina and Gustav. Change during Katrina was calculated between September 19, 2004 and August 31, 2005. Change during Hurricane Gustav was calculated between June 27-29, 2007 and September 8, 2008. 


\section{Horn Island}

Coastal change along Horn Island was highly variable alongshore; the standard deviations of shoreline and beach volume change exceeded the mean values (table 1, fig. 5). Intermittent peaks in change, both positive and negative, were, in part, related to the pre-storm morphology (fig. 2). For example, the changes in shoreline position, beach volume, and dune elevation were near zero where dune heights exceeded $3 \mathrm{~m}$ (fig. 2; longshore location, y $190 \mathrm{~km}$ ). The location of maximum shoreline and beach erosion $(\mathrm{y}=185 \mathrm{~km})$ corresponds to a local low in dune elevation (less than $2 \mathrm{~m}$ ), which, based on observations of overwash, was likely submerged by surge and waves during the peak of the storm. Additionally, the beach was very narrow (less than $50 \mathrm{~m}$ from shoreline to dune crest) on this low section of coast, allowing for more interaction of the waves with the dunes, and resulting in increased dune erosion (fig. 5).

A longshore pattern of adjacent shoreline erosion and accretion (wavelength was approximately 2-3 km) is similar to what was observed following Hurricane Katrina (fig. 4). Historical (150-yr) rates of shoreline change also show a pattern of shoreline retreat and accretion (Miller and others, 2004); however, the wavelength is two to three times that of the storm scale. The relationship between these long-term and short-term patterns of shoreline change will have consequences for the long-term evolution of coastline shape.

\section{Petit Bois Island}

Magnitudes of shoreline and beach volume change on Petit Bois Island were similar to those measured on the adjacent Horn Island (table 1, fig. 6). However, there was less spatial variability in the response on Petit Bois Island; standard deviations were much lower than those for Horn Island. No relationship between pre-storm dune elevation and magnitude of coastal change was observed.

Changes to dune/berm elevations were near zero along most of the island (table 1; fig. 6). However, isolated locations of elevation change greater than $0.75 \mathrm{~m}$ were observed on the east end of the island, where larger dunes with pre-storm elevations of more than $2.5 \mathrm{~m}$ were located only $50 \mathrm{~m}$ from the shoreline. The close proximity to the shoreline allowed for wave attack during the storm and subsequent erosion of the dune face. 

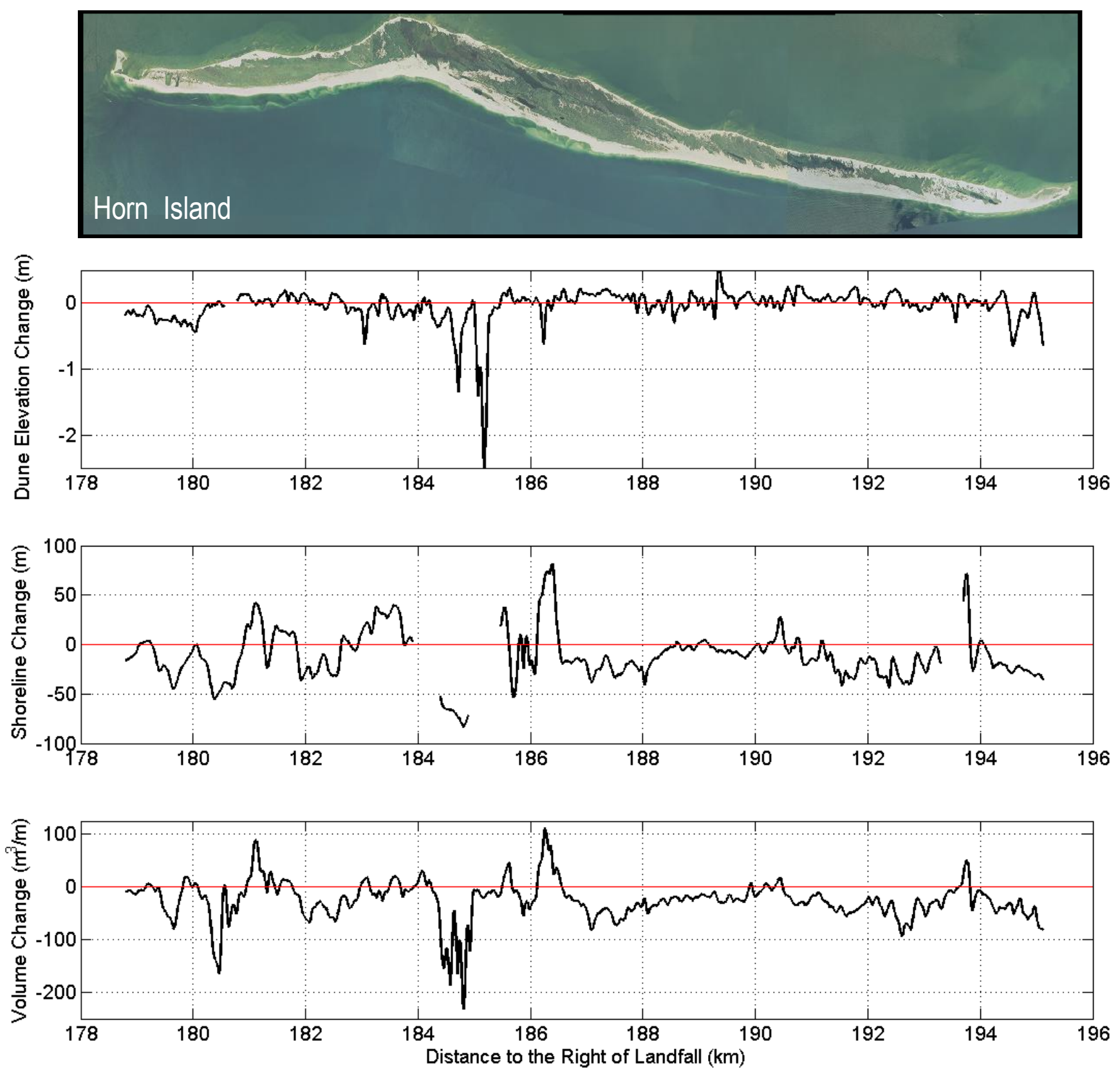

Figure 5. Aerial photograph taken by the U.S. Department of Agriculture on September 17, 2007. Dune elevation (top), shoreline (middle), and beach volume (bottom) changes for Horn Island, calculated between June 27-29, 2007 and September 8, 2008. 


\section{Petit Bois Island}
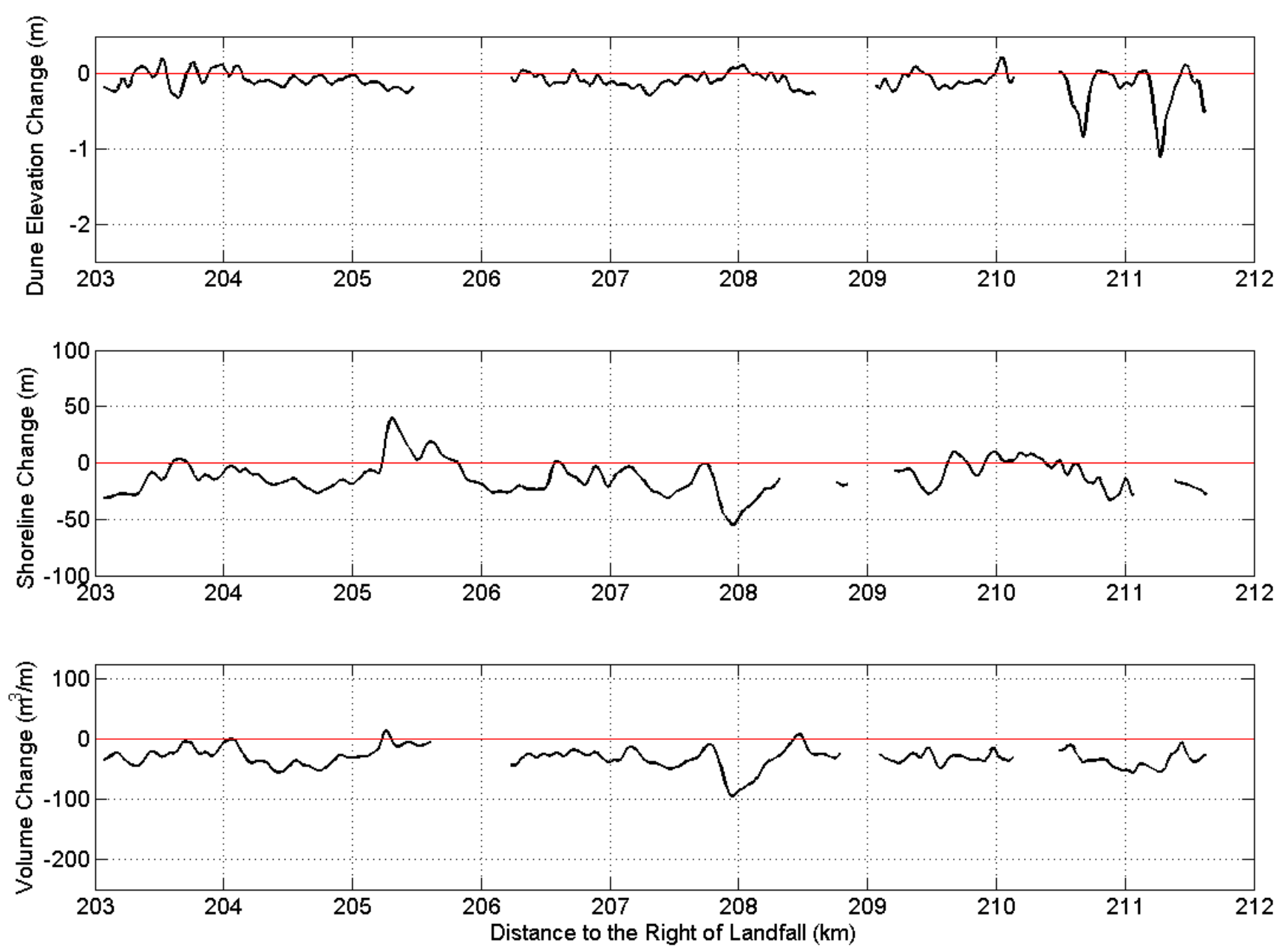

Figure 6. Aerial photograph taken by the U.S. Department of Agriculture on September 17, 2007. Dune elevation (top), shoreline (middle), and beach volume (bottom) changes for Petit Bois Island, calculated between June 2729, 2007 and September 8, 2008. 


\section{Discussion}

The landfall of Hurricane Gustav occurred 150 to $200 \mathrm{~km}$ west of East Ship, West Ship, Horn, and Petit Bois Islands. However, a local storm surge of 1 to $3 \mathrm{~m}$ and nearshore waves with heights in excess of $6 \mathrm{~m}$ caused marked coastal change along their Gulf-front coastlines.

Hurricane Gustav, with category 2 strength winds at landfall, contributed nearly as much to the geomorphic evolution of the islands as did Hurricane Katrina (category 3), which made landfall $150 \mathrm{~km}$ closer to the Mississippi barriers with higher winds and a lower central pressure (Knabb and others, 2006; Bevin and Kimberlain, 2009). Magnitudes of shoreline change during Hurricane Gustav along the islands were generally of the same order as change observed following Hurricane Katrina. Erosion of dunes during Hurricane Katrina appears to have increased the islands' vulnerability to further shoreline retreat, dune height reduction, and volume loss during the less powerful storm conditions associated with Hurricane Gustav.

The coastal response was spatially variable across the region - locations of erosion, accretion, and no change were observed on each island. In some places, pre-storm island morphology, such as dune height and beach width, contributed to patterns in the observed response. An analysis of the local subsurface and offshore geology and of the fluid forcing by waves and surge may provide additional insight into causes for the alongshore variability in storm response.

Consideration of the long-term evolution of the islands may provide a greater understanding of their behavior during Gustav, as well as implications for future responses. The historical rates of coastal change along the Mississippi barriers are higher than along other morphologically comparable island chains along the S.E. Atlantic coast (Morton and others, 2004; Morton and Miller, 2005). This is due to the long-term migration patterns of the GUIS islands, the lack of a sediment source for natural recovery of sandy beaches, and a relative rise in sea-level. Large waves and surge that accompanied Hurricane Gustav served to reinforce these background trends in coastal change. In areas where shoreline retreat exceed approximately $10 \mathrm{~m}$, the magnitude of hurricane-induced erosion was comparable to what the island might experience over a decade of average wave conditions, given local long-term erosion rates. In more extreme cases, storm-induced island breaching, such as on East Ship Island, contributed to direct land losses and created channels that allowed erosive waves and currents to impact larger portions of the island (Morton, 2008). Without time to recover between successive hurricane landfalls, the storm-induced coastal change contributed to, and possibly accelerated, the degradation of these dynamic islands. 


\section{References Cited}

Bevin, J.L. II, and Kimberlain, T.B., 2009, Tropical cyclone report Hurricane Gustav: National Oceanic and Atmospheric Administration National Hurricane Center Report AL072008, 36 p.

Bonisteel, J., Nayegandhi, A., Brock, J.C., Wright, C.W., and Nagle, D.B., 2009, Experimental Advanced Airborne Research Lidar (EAARL) data processing manual: U.S. Geological Survey OpenFile Report 2009-1078, 38 p.

Boone, P.A., 1973, Depositional systems of the Alabama, Mississippi, and western Florida coastal zone, Transactions - Gulf Coast Association of Geological Societies, 23, p. 266-277.

Byrnes, M.R., R.A. McBride, S. Penland, M.W. Hiland and K.A. Westphal, 1991, Historical changes in shoreline position along the Mississippi Sound barrier islands, Proceedings 12th Annual Research Conference. Coastal Depositional Systems in the Gulf of Mexico: Quaternary Framework and Environmental Issues. Gulf Coast Section SEPM, p. 43-55.

Doran, K.S., Stockdon, H.F., Plant, N.G., Sallenger, A.H., Guy, K., Serafin, K.A., 2009, Hurricane Gustav: Observations and Analysis of Coastal Change: U.S. Geological Survey Open-File Report 2009-1279, $28 \mathrm{p}$.

Hopkins, G., 2009, email regarding surge levels in Gulf Islands National Seashore (personal communication November 5, 2009).

Knabb, R.D., J.R. Rhome, and D.P. Brown, 2006, Tropical cyclone report for Hurricane Katrina: National Oceanic and Atmospheric Administration National Hurricane Center Report AL122005, $43 \mathrm{p}$.

Miller, T.L., R.A. Morton, A.H. Sallenger and L.J. Moore, 2004, National assessment of shoreline change: A GIS compilation of vector shorelines and associated change data for the U.S. Southeast Atlantic Coast: U.S. Geological Survey, Open-File Report 2004-1089.

Morton, R.A., Miller, T.L. and Moore, L.J., 2004, National Assessment of Shoreline Change: Part 1: Historical Shoreline Change and Associated Coastal Land Loss along the U.S. Gulf of Mexico: U.S. Geological Survey Open-file Report 2004-1043, 44 p.

Morton, R.A. and Miller, T.L. , 2005, National Assessment of Shoreline Change: Part 2: Historical Shoreline Change and Associated Coastal Land Loss along the U.S. Southeast Atlantic Coast: U.S. Geological Survey Open-file Report 2005-1401, 40 p. 
Morton, R.A. , 2008, Historical changes in the Mississippi-Alabama barrier-island chain and the roles of extreme storms, sea level, and human activities: Journal of Coastal Research, vol. 24, no. 6, p. 15871600 .

National Data Buoy Center, 2008, Reports from the National Data Buoy Center's stations during the passage of Hurricane Gustav: National Oceanic and Atmospheric Administration, Accessed at http://www.ndbc.noaa.gov/hurricanes/2008/gustav on June 4, 2009.

Plant, N.G., Holland, K.T. and Puleo, J.A., 2002. Analysis of the scale of errors in nearshore bathymetric data: Marine Geology, vol. 191, p. 71-86.

Stockdon, H., Sallenger, A., List, J., and Holman, R., 2002, Estimation of shoreline position and change using airborne topographic lidar data: Journal of Coastal Research, vol. 18, no. 3, p. 502-513.

Stockdon, H.F., Doran, K.S., and Sallenger, A.H., 2009, Extraction of lidar-based dune-crest elevations for use in examining the vulnerability of beaches to inundation during hurricanes: Journal of Coastal Research, Special Issue 53, p. 59-65.

Weber, K.M., List, J.H., and Morgan, K.L.M., 2005, An operational mean high water datum for determination of shoreline position from topographic lidar data: U.S. Geological Survey Open-File Report 2005-1027. 